\title{
On some poorly known or unrecognized verbal categories in Soqotri: 1905-2015
}

\author{
Leonid Kogan* \\ Russian State University for the Humanities \\ lkog@rggu.ru \\ Maria Bulakh \\ Russian State University for the Humanities \\ mbulakh@mail.ru
}

\begin{abstract}
The article deals with two hitherto unexplored - to some extent, even unknownverbal categories of the Modern South Arabian language Soqotri (Island of Soqotra, Gulf of Aden, Yemen), namely the "old imperative" and the $n$-conditional. Research material is taken from both the early publications of the Austrian expedition and the authors' own field materials recently collected on the island. It is demonstrated that both categories have survived up to now and can be found-albeit not very frequently - in the living speech of the islanders. In the concluding segments of the article, a few hypotheses about the functional load of the categories under scrutiny are advanced and discussed.
\end{abstract}

\section{Keywords}

Modern South Arabian - Soqotri - verbal morphology - modality

* Maria Bulakh has provided the theoretical framework and functional analysis of the evidence in the second part of this contribution, dealing with the Soqotri $n$-conditional (project 34.5109.217 supported by the Russian Ministry of science and education). The remaining parts of the article have been written by L. Kogan (project 16-18-10343 supported by RSCF). It is a pleasant duty to express our warm gratitude to the anonymous reviewer for his constructive critical remarks and particularly for preparing the draft of the linguistic glossing for the text examples throughout the article. 


\section{Introduction}

In the present contribution we will deal with two verbal categories of Soqotri whose very existence has been neglected or, more often, explicitly denied in the scholarly literature during the past 110 years. This deplorable situation, of no small consequences not only for the study of Soqotri itself, but also for its broader comparative context within and outside MSA, has two fundamental reasons behind it. On the one hand, the proverbially rich and varied Soqotri text corpus collected and published by the outstanding Austrian semitist David Heinrich Müller has never been subject to serious linguistic analysis. On the other hand, for more than 80 years since the appearance of Müller's text collections, not a single line of new texts in Soqotri has been published. Vitaly Naumkin's important contributions of mid-1980s, which appeared in Russia and in Russian and were, therefore, of limited access for the Western scholarly community, did not seriously mitigate this negative trend.

Thanks to the recent advances achieved by the Russian-Yemeni working team, both obstacles can be said to be broadly overcome. On the one hand, the large amount of newly published Soqotri texts with detailed linguistic and philological annotations, emblematized by the recent Volume One of our Corpus of Soqotri Oral Literature, provides a wealth of phonologically and morphologically reliable linguistic evidence ready for further reflection and analysis. On the other hand, systematic perusal of Müller's corpus with the help of native speakers has become our constant source of inspiration in a variety of grammatical, lexical and folkloristic aspects. ${ }^{1}$

\subsection{History of research}

That order and command in Soqotri are usually expressed by the Imperfect rather than by the Jussive-based "Old Imperative" (as in the majority of other Semitic languages including continental MSA) is an obvious and widely recognized fact which hardly requires any further comment. At the same time, Ewald Wagner's pointed remark of 1953:11 still preserves its validity: "Schwierig ist die Frage, ob sich im Soq. auch noch alte Imperative erhalten haben, zu beantworten".

1 For a large-scale attempt at "revitalization" of the "Vienna Corpus" of Soqotri texts v. Naumkin et al. 2015 . 
According to the majority view, going back to Maximilian Bittner's early observations ${ }^{2}$ and codified by the standard tools of today's comparative grammar of MSA, the "Old Imperative" simply does not exist in Soqotri. ${ }^{3}$ Perhaps the most explicit statement representing this way of thought is due to Antoine Lonnet: 'Le Soqotri n' a pas d' impératif, l' ordre se donnant à l' inaccompli indicatif. Or certains auteurs ont été trompés par un indicatif sans préfixe dans lequel ils ont cru voir une forme d' impératif" (Lonnet 1993:74).

However, even Ewald Wagner's preliminary survey of the Soqotri evidence from the Vienna corpus (1953:11-12) makes it obvious that the "Old Imperative" is not totally alien to Soqotri. Wagner was not yet aware of the fact that the loss of the $t$-prefix in the Imperfect can only occur in certain derived stems (first and foremost, the intensive and the causative), but never in the active voice of the basic stem: it was a few decades later that this important rule was discovered by T.M. Johnstone. ${ }^{4}$ In spite of this, and on partly intuitive grounds mentioned on p. 12 of his study, Wagner successfully identified more than a dozen relevant forms scattered over the pages of Müller's 1905 and 1907 volumes.

As Wagner correctly observes, the existence of the "Old Imperative" is regularly (even if not always correctly) acknowledged on the pages of Wolf Leslau's Lexique Soqotri. Also T.M. Johnstone must have been aware that such forms are not totally missing at least from the Vienna corpus-even if, as we will see below, his evaluation of their presence in Müller's texts can only be qualified as a crass understatement. ${ }^{5}$

\section{2}

\section{The evidence}

Let us now proceed to the material evidence ensuing from a complete perusal of the Vienna corpus (SAE IV, VI and VII as well as Bittner 1918b) and the texts

2 "Beläufig gesagt, kommen Imperative im Soqoțri so gut wie gar nicht vor: sie werden durch Indikative ersetzt" (Bittner 1918a:73), "An Stelle des Imperativs gebraucht das Sq. immer den Indikativ" (Bittner 1917-1918:349), italics added.

3 Simeone-Senelle 1997a:404: "In Soqotri, command is expressed by the indicative imperfect". Nearly the same statement is found in Simeone-Senelle 2011:1096 and cf. 1997b:810: "The jussive [sic!] is expressed by the imperfect indicative".

4 For the synchronic and diachronic aspects of this remarkable phenomenon, shared by Soqotri with its sister tongue Jibbali, v. Bittner's pioneering observations in 1917-1918:347-351, followed by Johnstone 1968 and 1980, Testen 1992 and a recent summary description in Kogan 2015:471.

5 Johnstone 1968:516: "In Soqotri there is no imperative, the imperfect performing this function. One or two forms raise doubts as to whether this was always so, particularly in the poetic passages in $M S$, II, but the general principle cannot be doubted" (italics added). 
recorded by our team from today's Soqotri speakers (the recently published CSOL I and the forthcoming Volumes II and III of this serial edition).

1.2.1 The Vienna corpus: original prose

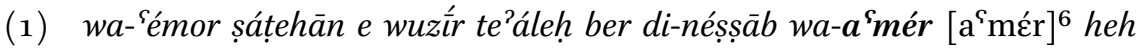
márkeb istó?oh

and=say:PST:3SG.M sultan:SG to vizier:SG call:NPST:2SG.M Son:SG POsS=bird_catcher:SG and=say:IMP:2SG.M to:3SG.M boat:SG be_ready:PST:3SG.F

'Und der Sultan sprach zum Wesir: Rufe den Sohn des Vogelstellers und sage ihm: Das Schiff ist fertig!' (SAE VI, 55:26-28)

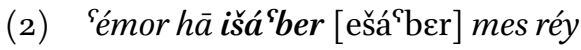
say:PST:3SG.M come_on take:IMP:2SG.M of:3SG.F head:SG

'Er sprach: Hier nimm die Spitze!' (SAE VI, 91:9)

(3) wa- 'émor héhi hayr héki ạ̣mío [ahmí?o] tho and=say:PST:3SG.M to:3DU better to:2 DU marry:IMP:2DU OBJ:1SG 'Er sprach zu ihnen: Es ist besser für euch, verheiratet sie mit mir' (SAE VI, 125:2-3, cf. the informant's Arabic gloss زوِّجاني

(4) $w a-{ }^{\varsigma}$ eméroh hes $a^{\S} b e r\left[a^{\varsigma} \mathrm{b} \varepsilon r\right]$ tho rího leré and=say:PST:3SG.F to:3SG.M deliver:IM P:2SG.M OBJ:1SG water:SG drink:JUs:1SG 'Sie sprach zu ihm: Reich mir Wasser zum Trinken!' (SAE VI, 127:13)

(5) wa- 'émor hes 'orḥik [órhị] dé harz id nașf and=say:PST:3SG.M to:3SG.F take_away:IMP:2SG.F this:SG.M amulet:SG towards side:sG

'Und er sprach zu ihr: Entferne dieses Amulett auf die Seite' (SAE VI, 189:19, Wagner 1953:12)

6 Throughout the examples from the Vienna corpus, the relevant forms of the Old Imperative and the $n$-conditional are accompanied by their reconstructed phonological transcription according to the known morphological rules of today's language (in square brackets). Initially, it was expected to check them with the native speakers, but the current situation in Yemen did not give us such a chance.

7 Mistaken for a non-prefixed imperfect in Johnstone 1968:521.

8 Mistaken for a non-prefixed imperfect in Johnstone 1968:521. 
1.2.2 The Vienna corpus: translated prose ${ }^{9}$

(6) érid [éred] 'érehon w-ithér [ețhér] $w$-úr's $\left[\mathrm{er}^{\varsigma} \mathrm{é}\right]$ water:IMP:2PL.M goat:PL and=go:IMP:2 PL.M and=graze:IMP:2PL.M 'Tränket die Schafe und geht und weidet [sie]' (SAE VI, 7:19-20, Genesis 29:7 = (اسقوا الغنم واذهبوا ارعوا

(7) $a^{\varsigma}$ ád [a'ád] $a^{\varsigma}$ tíber [a'téber] šețaífo di-ohóke go:IMP:2SG.M look:IMP:2SG.M well_being:SG POsS=brother:PL-POSS:2SG.M

'Geh und sieh nach dem Wohlbefinden deiner Brüder' (SAE VII, 47:16-17, Genesis 37:14 = اذهب انظر سلامة إخوتك)

(8) wa- 'émor ho le agében ó eho eẓáh [eẓ̣̂áa $]$ hó?o iré e and=say:PST:3SG.M 1SG want:COND:1SG brother:PL-POSS.1SG tell:IMP:2SG.M where graze:NPST:3PL.M

'Und er sprach: Ich suche meine Brüder, gib mir Kunde, wo sie weiden! (SAE VII, 48:1-2, Genesis 37:16 = أخبرني أين يرعون)

(9) 'émor țād a 'alš ekféd [eḳféd] inzéf [enzéf] híki rího id káâse?er say:PST:3SG.M one:M to companion:SG-POsS.3SG.M go_down:IMP:2SG.M pour:IMP:2SG.M to:1DU water:SG towards waterskin:SG

'Der eine sprach zu seinem Genossen: Steig hinab und schöpfe für uns beide Wasser in den Schlauch' (SAE VII, 60:3-4, Wagner 1953:12)

(10) 'émor ákfad [ákfed] tho id 'ébehor say:PST:3SG.M make_go_down:IMP:2SG.M OBJ:1SG towards well:SG 'Er sagte: Laß mich in den Brunnen hinunter' (SAE VII, 63:12-13)

(11) 'émor hes șáṭehān eḳif [ćḳif] say:PST:3SG.M to:3SG.F sultan:SG be_silent:IMP:2SG.F 'Der Sultan sprach: Schweige!' (SAE VII, 67:23-24)

(12) 'émor șáțehān e ŝ́ybib emótil [emótil'] tan say:PST:3SG.M sultan:SG to old_woman:SG narrate:IM P:2SG.F OBJ:1PL 'Da sprach der Sultan zur Alten: Erzähle uns etwas!' (SAE VII, 67:27-28)

9 The original texts can be in Arabic, Mehri or Jibbali. 
(13) wu-fées heš dódehi fáhre wu-'émer heš iblég [eblẹg] tan diól hanāzîr nkebihin

and=request:PST:3PL.M to:3SG.M devil:PL all and=say:PST:3PL.M to:3SG.M send:IMP:2SG.M OBJ:1PL towards swine:PL

enter:JUS:1PL-OBJ.3PL.M

'Und es baten ihn die Teufel sämtlich und sagten zu ihm: Du sollst uns schicken hin zu den Schweinen, (daß) wir in sie hineingehen' (Bittner 1918b:106, Mark 5:12 = أرسلنا إلى الخنازير (10)

(14) iblég-ihin [eblegéyhen] kehór itéher id ḳu haríten w-id hádyob send:IMP:2SG.M-OBJ.3PL.M in_order_to go:NPST:3PL.M towards village:PL and=towards town:PL

'Du schickest sie, damit sie gehen in die Dörfer und in die Städte' (Bittner 1918b:136, Mark 6:136 = اصرفهم لكي يمضوا )

1.2.3 The Vienna corpus: poetry

(15) ahrí [ahrí] min ŝá $a r$ seek:IMP:2SG.F of fodder:SG

'Suche Futterkräuter' (SAE VI, 161:6, Wagner 1953:12)

(16) óškil [óškil'] hey Kírkim ber héberk w-ósli [ósli] tho min gad d'inkórkim wrap:IM P:2SG.F on:1SG Kirkim because feel_cold:PST:1SG and=bring:IM P:2SG.F OBJ:1SG of skin:SG REL=turn_yellow:PST:3SG.M 'Bedecke mich, Kirkim, denn ich friere, und bring hierbei deine Haut, die gelbe' (SAE VI, 167:15-16) $)^{11}$

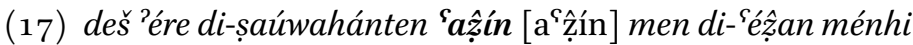
this:SG.F moon:SG POSS=little_light:PL love:IMP:2SG.F of REL=love:PST:3SG.M of.1SG

'Mond, du unter den kleinen Leuchten, liebe die, die mich lieben' (SAE VI, 168:18-19)

\footnotetext{
10 Bittner's remark "iblég ist nicht Imperativ, sondern 2 P. g. m. des Subj." is incorrect (same ibid. 137). Bittner's non-imperative German translations here and elsewhere below betray his reluctance to acknowledge the existence of the "Old Imperative" in Soqotri.

11 The former form mistaken for a non-prefixed imperfect in Johnstone 1968:520.
} 
(18) láḥmod 'anš wa-ḥmíd [ahmíd] 'ánhi love:JUS:1SG from:2SG.F and=love:IMP:2SG.F from:1SG 'Ich lieb' dich, du liebst mich' (SAE VI, 171:10, translation inexact)

(19) imlé? [emlé $]$ min siát 'íidi fill:IMP:2SG.M of fire:SG hand:DU

'Fülle deine Hände mit Feuer' (SAE VI, 181:17, Wagner 1953:12)

(20) w-'ágil [a'gíl'] hey minól 'egóref and=meet:IMP:2SG.F on:1SG where look_for_livestock:NPST:1SG 'Besuche mich bei meinen Herden' (SAE VI, 183:15)

(21) ilhíyo a rísis [a'réses] ínhi POSS.PL=1SG marry:IMP:2PL.M-OBJ.3SG.F to:1SG

'Verheiratet mich ihr, o meine Leute' (SAE VI, 188:30)

(22) 'eríd [ćrid] tho Šígrah ber țaimek water:IMP:2SG.F OBJ:1SG Š́grah because be_thirsty:PST:1SG 'Gib zu trinken mir Šigra, ich durste' (SAE VI, 188:16)

(23) 'aḥdíl [ahdíl'] sílsileh min géhe remove:IMP:2SG.F chain:SG of breast:SG 'Tu zur Seit' die Kette an der Brust' (SAE VI, 189:11, Wagner 1953:12)

(24) a Šígrah asḳil [a'ḳil'] metébib voc Š́́grah leave:IMP:2SG.F garment:SG 'O Šigra, leg' ab dein Gewand' (SAE VI, 195:7, Wagner 1953:12)

(25) ib 'íl [ebíl'] min 'éyūg kabáäl marry:IMP:2SG.F of man:PL tribesman:PL

'Heirate Männer aus Araberstämmen' (SAE VI, 202:17, Wagner 1953:12)

(26) a Šígrah a țtít [a'tít ] deš 'óben VOC Š́grah swallow:IMP:2SG.F this:SG.F stone.sG 'O Šígrah, schlinge diesen Stein da' (SAE VI, 205:10, Wagner 1953:12)

(27) iblíg [eblíg] hey min 'aíni démi send:IMP:2SG.F on:1SG of eye:DU sleep:SG

'Schicke mir von deinen Augen Schlaf' (SAE VI, 213:17, Wagner 1953:12) 
(28) 'orḳéh [órḳiḥ] måmídoh wa-háșer bring:IMP:2SG.F pillow:SG and=carpet:SG 'Bring Polster und auch Teppich hin' (SAE VI, 224:3, Wagner 1953:12)

(29) $\boldsymbol{e b}$ 'ér [eb'ír] fi di-ŝírehéten come_at_night:IMP:2SG.F in:1SG POSS=sail:PL 'Zieh' hin mit mir, o mein Segelschiff' (SAE VI, 241:3)

(30) ilhíyo wudkér [edkér] kanínhin wótkeh [óțke ${ }^{\varsigma}$ ] be-dí șéḳabéken POSS.PL=1SG and=remember:IMP:2PL.M Lord and=look_upwards:IM P:2 PL.M in=REL=create:PST:3SG.M-OBJ.2PL 'Ihr Menschen, gedenket des Herrn und blicket auf eueren Erschaffer' (SAE VI, 255:19-20)

(31) šomtéles [šomtéles] wuklé [eklé] bis 'áḳel talk:IMP:2PL.M-OBJ.3SG.F and=turn:IMP:2PL.M in:3SG.F understanding:SG 'Sprecht mit ihr, bringt sie zu Vestand' (SAE VI, 256:6, Wagner 1953:12)

(32) 'iz's [ez [ez'í] tho ședák di-Géwi take:IMP:2SG.F OBJ:1SG ship:SG POSS=Géwi

'Nimm mich auf, o Schiff des Géwi' (SAE VI, 263:6, Wagner 1953:12)

(33) áŝbaḥ $\left[\right.$ áŝa $\left.^{\mathrm{S}}\right]$ nhofk min ménihéten satiate:IMP:2SG.M REFL:2SG.M of beautiful:PL 'Sättige dich an den Schönen' (SAE VI, 264:15)

(34) a Šígrah ídkir [edkír] ḳanínhin wóṭeh [óțkị ${ }^{\varsigma}$ ] bid 'alálheníten vOC Šígrah remember:IMP:2SG.F Lord and=look_upwards:IMP:2SG.F in $=$ REL $=$ cloud:PL

'O Šígrah, denke Gott des Schöpfers und blicke hoch hinauf zu den Wolken' (SAE VI, 265:11-12)

(35) eblig [ebl'íg] hey min `aíni démi send:IMP:2SG.F on:ISG of eye:DU sleep:SG

'Schicke mir von deinen Augen Schlaf' (SAE VI, 279:15, practically identical to $(27))$

(36) ónzikíki [onzikí-ki] min o?órim make_turn:IMP:2SG.F-OBJ.1DU of road:SG 'Laß vom Wege uns abbiegen' (SAE VI, 280:21) 
(37) 'ódin ['ódin] í di-kalš te ódin sing:IMP:2SG.F 2SG.F REL=be_able:PST:2SG.F sing:JUS:2SG.F 'Singe du, der Gesang ist gegeben' (SAE VI, 282:3)

(38) ekléh [eḳlî́] fí Šígrah id kotli throw:IMP:2SG.F in:1SG Šígrah towards breast:DU 'Wirf mich Šígrah in deinen Busen' (SAE VI, 288:15)

(39) 'amér [a'mér] min 'ífk móḥmid make:IMP:2SG.M of father:SG-POsS.2SG.M waterskin:SG 'Aus deinem Vater mache einen Schlauch' (SAE VI, 296:10)

(40) ințéf [ențéf] di- २̊́ di-bébe break:IMP:2SG.M POSS=2SG.M POSS=father:S G

'Zerbrich doch deines Vaters (Armknochen)' (SAE VI, 296:22, Wagner 1953:12)

(41) dé Saurébhen ål tího tenádah índạ̣ [endás] léhem d'áżaḥ be-Serhéten this:SG.M little_raven:SG NEG OBJ:1SG peck:NPST:2SG.M peck:IMP:2SG.M shark:SG REL=fall:PST:3SG.M in=Serhéten 'O du kleiner Rabe, picke mich doch nicht; picke den Haifisch, der in Serhéten fiel' (SAE VI, 324:1-4)

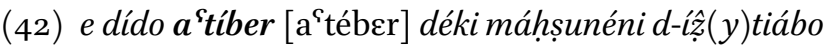
voc uncle:SG look:IMP:2SG.M this:DU crab:DU REL=bite_one_another:NPST:3DU.M 'O Oheim, sieh, wie sie [einander reißen], die beiden Krabben einander beißen' (SAE VI, 324:12-13)

(43) áḥdel [aḥdél] nháfk san hạalf ḥeṣhin take_away:IMP:2SG.M REFL:2SG.M from sharp_edge:SG iron:SG 'Halte dich fern von der Spitze des Eisens' (SAE IV, 172 No. 28)

(44) šáḥbir [šáḥber] wa-hábir [áḥber] Madába be_informed:IMP:2SG.M and=inform:IMP:2SG.M Madába 'Theile es mit, verkünde es in Medaba' (SAE IV, 178 No. 43$)^{12}$

12 For the relevant verbs $h^{a}$ ber (IV) and šh $h^{a}$ ber (x) v. Naumkin et al. 2014:552. Both are specifically connected with informing/being informed of somebody's death and thus fit 
(45) îsgir [ê̂gír] wa-taír Hairébe

close:IM P:2SG.F and=hold:IMP:2 SG.F Hairébe

'Schliesse und mach gut zu, o Hairebe' (SAE IV, 184 No. 57, Wagner 1953:12)

1.2 .4

CSOL I and II

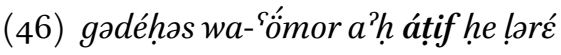

come:PST:3SG.M-OBJ.3SG.F and=Say:PST:3SG.M INTERJ give:IMP:2SG.F on:1SG drink:JUs:1SG

'He came up to her and said: Please give me something to drink!' (CSOL I, $7: 6$ and passim in this text) ${ }^{13}$

(47) il'-bə-țarérhen moŝórih ạ̣béron he bar șámik

REL.PL=in=Tarérhen young_palm:PL inform:IMP:2 PL.F on:1SG that die:PST:1SG

'Oh young palms in Tarerhen, make it known (to the people) that I am dead' (CSOL I, 27:14, poetry)

(48) $a^{2} h$ ḳáḳa otréb ídhi

INTERJ brother:SG come_down:IMP:2SG.M towards:1SG

'Oh my brother, come down to me!' (CSOL I, 8:25)

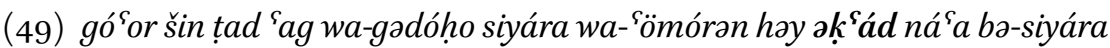
fall_ill:PST:3SG.M with:1PL one:M man:SG and=come:PST:3SG.F car:SG and=say:PST:1PL to:3SG.M go_down:IMP:2SG.M now in=car:SG 'One person among us fell ill. A car came to bring him to the hospital, and we said to him: Please get in the car!' (CSOL I, 8:25)

the context of the poem in which they are attested. Müller's translation, where the two verbs are presented as synonyms ('theile es mit, verkünde es'), is inexact, translate rather 'be informed and inform (others)', cf. the Arabic translation أعلم وعلّ , presumably for the I and II stems respectively. Note that šh̆aber (x) 'to be informed of somebody's death' is not identical to šhábir $\left(\mathrm{x}_{\mathrm{II}}\right)$ 'to inquire'.

13 In the text examples from $\mathrm{CSOL}$, the phonetic notation distinguishing between $ə$ and $e$ is maintained, in spite of its approximate and certainly non-phonemic nature. In the paradigms (as well as in the normalized forms supplied in square brackets throughout this article) a strictly phonemic notation with $e$ is used instead. The occasional use of please in the translations reflects the informants' perception of the functional load of these forms, for which see below in the next section. 
(50) 'ámok e-di'yho 'ouyźghen tahóra háyki man óoz di-'â'yag boḳ ba-fádhon

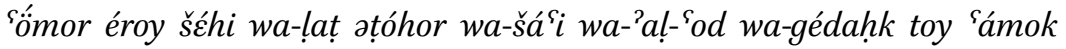
əšérḳa nạ ná'a wa-təkósas

say:PST:1S G to=POSS:1SG boy:SG search:NPST:2SG.M to:1DU of goat:SG REL=give_birth:NPST:3SG.F there in=mountain:SG say:PST:3SG.M drink:NPST:1SG tea:SG and=then go:NPST:1SG and=dally:PST:3SG.M and=NEG=go:PST:3SG.M and=come:PST:1SG OBJ.3SG Say:PST:1SG go_out:IMP:2SG.M now and=find:NPST:2SG.M-OBJ.3SG.F

'I told my son: Go and look in the mountains for our goat that is about to give birth. He said: I will finish my tea and then go. But he dallied and did not go. Then I came to him and said: Please leave and find it!' (CSOL I, 8:25)

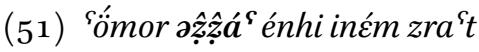
say:PST:3SG.M tell:IM P:2SG.M to:1SG what plant:PST:2SG.M

'He said: Tell me what have you planted?' (Naumkin et al. 2013:529, Segment 6)

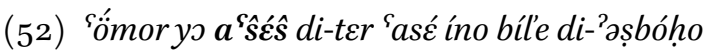
say:PST:3SG.M INTERJ stand_up:IMP:2SG.M towards=door:SG perhaps there_is thing:SG REL=appear_in_the_morning:PST:3SG.F

'He said: Please stand up (and come) outside-perhaps something new has appeared in the morning?' (CSOL II, 1:76, forthcoming)

(53) wa-ḥeb Šší o oțíbin ćkin ŝ́bib wa-kalíbo and=indeed on:2SG.F come_without_permission:NPST:1SG be:IMP:2SG.F old:SG.F and=decrepit

'And to you I will come without permission, be old and decrepit' (CSOL II, 24:12, poetry, forthcoming $)^{14}$

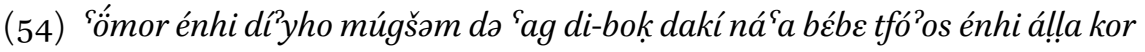
ékan tó?o toš 'ámok Éken tóo toy say:PST:3SG.M to:1SG POSS=1SG Son:SG this:SG.M man:SG REL=there intelligent:SG.M now father:SG request:NPST:2SG.M to:1SG God so_that be:NPST:1SG as OBJ:3SG.M Say:PST:1SG be:IMP:2SG.M as OBJ:3SG.M 'My son said to me: This man is very intelligent. Oh my father, pray God for me so that I become like him! I said: Please do become like him!' (CSOL II, 24:12, forthcoming)

14 The passage is not quite clear, but one can assume that we are dealing with a curse ('become old an decrepit!'). 
(55) țahérki ho wa-țad ḷ-ker ŝorț 'af tó'o eráhki 'amk di-ŝorț siníki 'ag máskin wa-bisisi šay daráham hédak wa-yafóos sömor dỉyho șáhab hiš ah 'al'éyk

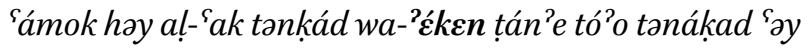
go:PST:1DU 1SG and=one:M on=over street:SG until when come:PST:1DU middle POSS=street:SG see:PST:1DU man:SG poor:SG.M and=there_is_not with:3SG.M money:PL be_dirty:PST:3SG.M and=request:NPST:3SG.M say:PST:3SG.M POSS=1SG friend:SG to:3SG.M INTERJ on:2SG.M say:PST:1SG to:3SG.M NEG=still_do:PST:2SG.M blame:JUS:2SG.M and=be:IMP:2SG.M thus as blame:NPST:2SG.M on:3SG.M 'We passed by a street, a friend of mine and me, and midway along we saw a poor man who had no money, a dirty one, who was begging. My friend said to him: Hush! Shame on you! But I said to him: Do not blame him (or) become like (him), (in the same state) as (the one for which) you blame him' (CSOL II, 24:12, forthcoming)

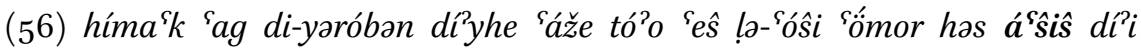
ambórye wa-lat șóbih 'améro hay wa-éhen 'ómor ho al-téma ${ }^{\varsigma} k$ 'améro hay

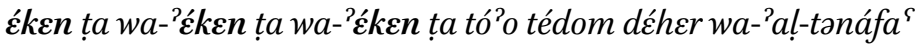
hear:PST:1SG man:SG REL=instruct:NPST:3SG.M POSS $=3 \mathrm{SG} . \mathrm{M}$ woman:SG when get_up:PST:3SG.M on=morning say:PST:3SG.M to:3SG.F wake_up:IMP:2SG.F POSS=2SG.F child:PL and=then gather_goats_in_the_morning:NPST:2SG.F say:PST:3SG.F to:3SG.M and=2SG.M say:PST:3SG.M 1SG NEG=be_able:PST:1SG Say:PST:3SG.F to:3SG.M be:IM P:2SG.M thus and=be:IMP:2SG.M thus and=be:IMP:2 SG.M thus when sleep:NPST:2SG.M always and=NE G=work:NPST:2 SG.M

'I've heard a man instruct his wife when he got up in the morning: Wake up the children and then go to gather the goats. She said: And what about you? He said: I can't. She said: Be this and this and this ${ }^{15}$ since you always sleep and do not work' (CSOL II, 24:12, forthcoming)

(57) lósșim 'ank bíyyo árḳạ̣ tho səké tó?o nísik tok die:JUs:1SG from:2SG.M (POss-)mother:SG expel:IMP:2SG.M OBJ:1SG out because forget:PST:1SG OBJ:2SG.M 'I would die for you, my baby: (feel free to) throw me away as a useless thing since I forgot you!' (CSOL II, 25:11, poetry, forthcoming)

15 A mild curse. 


\subsection{Morphological and functional analysis}

The complete paradigm of the "Old Imperative" as elicited from our informants for the basic stem (active and inactive types) looks as follows (the sample verbs are bélog 'to send' and zéged 'to carry').

\begin{tabular}{|c|c|c|c|c|}
\hline \multicolumn{2}{|c|}{ sg. } & \multirow[t]{2}{*}{ du. } & \multicolumn{2}{|c|}{ pl. } \\
\hline $\mathbf{m}$. & f. & & m. & f. \\
\hline $\begin{array}{l}\text { eblég } \\
\text { ezgód }\end{array}$ & $\begin{array}{l}\text { eblíg } \\
\text { ezgíd }\end{array}$ & $\begin{array}{c}\text { eblégo } \\
\text { ezgédo/ezgído }\end{array}$ & $\begin{array}{l}\text { eblég } \\
\text { ezgéd }\end{array}$ & $\begin{array}{l}\text { eblégen } \\
\text { ezgéden }\end{array}$ \\
\hline
\end{tabular}

The paradigm was produced, with no sign of doubt or difficulty, by three native speakers, male and female, from ca. 25 to ca. 43 years old, which is a telling witness of the fact that this form, while "Old" in terms of the linguistic nomenclature (and, indeed, not very common in the extant texts), is neither dead nor moribund, but well familiar to today's inhabitants of the island, including those belonging to relatively young generations.

Most of the $\mathbf{6 8}$ relevant forms collected from the texts belong to the basic stem: examples (1), (6), (7), (8), (9) (twice), (11), (13), (14), (15), (17), (18), (19), (20), (23), (24), (25), (26), (27), (29), (30), (31), (32), (34), (35), (38), (39), (40), (41), (43), (45) from the Vienna corpus (31 cases); examples (48), (49), (51), (52), (53), (54), (55), (56) (four times) from CsOL (11 cases). The structural difference between such forms and the corresponding forms of the imperfect (which, at any rate, always preserve the $t$-prefix) is so patent (-bleg-vs. -boleg-) that any kind of confusion between them is virtually excluded.

Worth of special notice are the examples (7) ( $\left.a^{5} a ́ d\right)$ and (53)-(56) (sg. m.

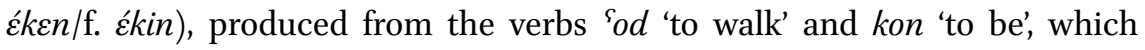
are among the most prominent remnants of the "hollow" type of weak verbs in Soqotri. ${ }^{16}$ Both forms display a prosthetic vowel, in spite of the fact that, differently from the strong verb, the first two radicals in their "Old Imperative" do not form a cluster. This might be due to analogy with the "Old Imperative" forms of the causative stem verbs of the type I' (átaf 'give!', átar 'hold!'), where

16 Naumkin et al. 2016:37. Note that the Jibbali cognate of ' $O d$ is a I $w$ verb agád (JL 288) and, in theory, the imperative $a^{\varsigma} a ́ d$ may be a remnant of a similar once existing by-form in Soqotri (suggestion of the anonymous reviewer). 
the first radical (stemming from either ${ }^{* ?}$ proper or ${ }^{*} w$ ) is dropped in the perfect, leaving a biconsonantal structure superficially similar to the "classical" hollow type (țef 'to give', ter 'to hold', from " $w t \underline{t} f{ }^{17}$ and $w t \underline{t} r^{18}$ respectively).

In the causative stem, the Vienna corpus has produced examples (3), (4), (5), (6), (10), (16) (twice), (21), (22), (28), (30), (33), (34), (36), (44) (15 cases); what we find in Csol are examples (46), (47), (57) (3 cases). Here again, the morphological structure of the imperative is totally different from that of the imperfect without the $t$-prefix (árkah vs. rákah) so that no confusion between the two sets of forms is possible, in spite of the loss of the prefix in the latter set.

Other derived stems are less commonly represented: (12), (37) for D (II), (7), (42) for Gt (VIII), (2), (31), (44) for Št (x) in the Vienna corpus; (50) for Št in CSOL (8 examples altogether). Here too, the distinction between the "Old Imperative" and the imperfect without prefixes is usually quite transparent: absence of the $n$-ending in the D stem, ${ }^{19}$ structural difference (and no loss of the $t$-prefix) in the Št stem ("Old Imperative" ešérḳah vs. imperfect $t$-šerákah from šérkah 'to go out'), etc.

Much more difficult to detect is the functional (or any other) distribution between the two ways of expressing order and command in Soqotri. ${ }^{20}$

Our informants insist that the imperfect is the neutral, unmarked representative of this category, whereas the "Old Imperative" is used when a particularly polite order is intended ("please go!"). Typologically, this is quite a feasible possibility: the innovative form is likely to assume the most basic grammatical function, relegating the old one to more peripheral usages. It would also-at least partly - explain why the "Old Imperative" is so uncommon in the published Soqotri texts: because of its marked, specific functional value, it is less likely to surface in a relatively restricted body of text evidence.

The latter remark brings us to the interesting question of the genre distribution of the "Old Imperative". The comprehensive evidence obtained in the course of our research yields the following statistics:

17 Cf. Arabic $w \underline{d} f$ 'to appoint, to assess (work, rations)', wadīffat- 'daily allowance, portion of food; an appointed instalment' (Lane 3056).

18 Identical with Jibbali éd

19 Contrast emótil' 'talk!' and motílin 'you talk', the 2 sg. f. "Old Imperative" and Imperfect from mótil' 'to talk'.

20 One can state from the onset that the functional opposition cannot be too drastic in this case, particularly since the "Old Imperative" and the Imperfect can appear as coordinated constituents within a single phrase with the imperative meaning (as in the examples [1] and [50]). 


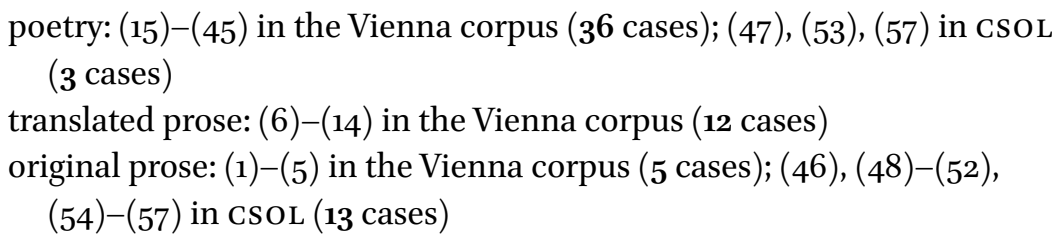

While the separate scoring for original and translated prose does not seem to be meaningful for the problem under scrutiny, ${ }^{21}$ the high concentration of the "Old Imperative" in the poetic corpus (particularly in the Vienna texts) is a matter of fact, which did not escape Wagner's attention: "Die erwähnten Imperativformen finden sich hauptsächlich in den Gedichten, in denen sie gegenüber den gewöhnlichen imperativischen Indikativen sogar überwiegen. ${ }^{22}$ In der Poesie wird sich eben eine alte Form erhalten haben, die in der Prosa fast ausgestorben ist". One willingly agrees with Wagner's belief that the high concentration of the "Old Imperative" forms in the poetic part of the Vienna corpus may be due to the archaic pitch of the Soqotri poetry as a whole, even if one has to bear in mind that a substantial part of the poetic fragments produced by Müller's informant do not seem to bear any stamp of great antiquity, but rather look as ad hoc creations stemming from his own circle and generation.

A more powerful argument is perhaps of metrical nature. Most of the Soqotri poetry consists of isometric eight-syllable lines, and here the difference between the trisyllabic forms of the imperfect and the bisyllabic imperatives becomes quite crucial: to replace the former by the latter means to spare a metrically superfluous syllable with no essential change in the meaning of the poem. Admittedly, this explanation would not suit the (not very numerous, but still significant) group of examples belonging to the causative stem: here, due to the loss of the $t$-prefix, the two sets of forms are both bisyllabic.

21 Thus, there is no reason to believe that the use of the "Old Imperative" in the Soqotri text is in any way conditioned by the presence of the corresponding form in the original: in the majority of cases, the Arabic, Mehri and Jibbali imperatives are routinely rendered by Soqotri imperfects. At any rate, the hypothetical assumption that the "Old Imperative" has been secondarily re-introduced under the influence of Arabic and/or continental MSA can be safely discarded in view of the clearly archaic, residual nature of this set of forms.

The correctness of the latter part of this statement can only be verified via a comprehensive statistical analysis which remains to be carried out. That the imperfect in the imperative function is by no means a rarity in the poetic corpus is, at any rate, quite certain. 


\subsection{History of research}

The history of research on the MSA $n$-conditional is not free of paradoxes. The first scholar who dealt with this verbal category was Ewald Wagner, for whom the sporadic presence of such forms in apodoses of unreal conditional sentences of the Soqotri poetic pieces from the Vienna corpus was the only remnant of the Proto-Semitic $n$-energetic: "In Nachsatz zu diesen Konditionalsätzen steht $l$ - (gleich arab. la-) mit folgendem Energicus, der sich nur hier im Nsa. erhalten hat" (1953:152). ${ }^{23}$ Given the nature of the text corpora available to Wagner, this conclusion is not surprising: as we know it today (Watson 2012:9192), the $n$-conditional is missing from the Western and Central varieties of Mehri, which were the only ones available to Wagner from the extensive text collections published by the members of the Austrian expedition, whereas Müller's Jibbali corpus, rather limited in size and not always quite reliable, very rarely provides pertinent syntactic slots. ${ }^{24}$

The appearance of Johnstone's data on the MSA idioms of Dhofar (Jibbali and Omani Mehri) marked a radical reversal of the scholarly attitude towards the $n$-conditional. In his classical summary description of MSA (1975:110), Johnstone speaks of "a further subjunctive formation which, to the best of my knowledge, is not described in the earlier literature" and surmises that "it is possible ... that comparable forms do not occur south of Dhofar". 25

In the wake of Johnstone's discoveries, the specific association of the $n$ conditional with the Dhofar area has become a matter of scholarly consensus, as reflected in several standard tools of MSA grammar of the last decades. ${ }^{26}$

23 And cf. Wagner 1993:337, in response to Harry Stroomer's publication of Johnstone's Mehri texts: "Bisher war der Konditional nur aus poetischen Texten des Soqoțri bekannt".

24 Our own systematic perusal of the Jibbali sections of SAE VII reveals two examples of an unreal conditional clause (77:12-14 and 89:21-25), in which the perfect is used in both the protasis and the apodosis (Wagner 1953:151). Note, however, that at least one example of a free-standing $n$-conditional has been found in SAE VII 10516 .

25 Johnstone does not mention at all the existence of the $n$-forms in Müller's Soqotri texts, nor the fact that Wagner, more than twenty years before him, had been able to identify their principal function exactly in the same way as he did for Mehri and Jibbali. A certain lack of attention to the work of his Austrian predecessors is, indeed, a well-known feature of Johnstone's working method (cf. Rubin 2010:10).

26 Lonnet 1993:72 ("les langues du Dhofar ont aussi un 'conditionnel'), Simeone-Senelle 1997a:404 ("the conditional does not occur in the Mehri of Mahra or in Soqotri", same 2011:1096) and elsewhere. 


\subsection{The evidence}

2.2.1 The Vienna corpus: original prose

(58) karáme di-lóṣmien [ḷoṣmíin] wa-kấnoh šek hạáge tṭóhor wa-tehófer nḥat móbrek di-gimál mes šém Sarsêreh

if REL=die:COND:1SG and=be:PST:3SG.F with:2SG.M need:SG

go:N PST:2SG.M and=dig:N PST:2SG.M under halt:SG POSS=camel:SG of:3SG.F name:sG Sarsếreh

'Wenn ich gestorben bin und du Not hast, sollst du hingehen und graben unter der Lagerstätte des Kamels, dessen Name Sarsāra ist' (SAE VI, 45:1719)

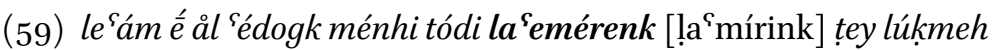
if 2SG.M NEG suck:PST:2SG.M of:1SG breast:SG make:COND:1SG-OBJ.2SG.M one:F morsel:SG 'O, wenn du aus meiner Brust nicht gesaugt hättest, würde ich dich als (zu) einen Bissen verschlucken (machen)' (SAE VI, 92:1-2, Wagner 1953:152)

(6o) ke lóṣmien [ḷoṣmíin] emárațki

if die:COND:1SG admonish:NPST:1SG-OBJ.2DU

'Wenn ich gestorben bin, testiere ich euch' (SAE VI, 98:2)

(61) ke lóṣmien [loṣmíin] 'a-lirét šíki

if die:COND:1SG NEG=inherit:JUS:3SG.M with:2DU

'Wenn ich sterbe, soll er mit euch nicht erben' (SAE VI, 98:10)

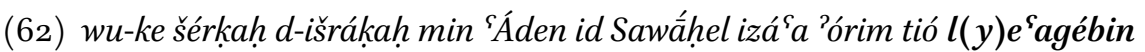
[l'a'gíbin] ${ }^{\varsigma} O m a \bar{n} n^{27}$

and=if go_out:PST:3SG.M REL=go_out:NPST:3SG.M of Aden towards Sawâhil take:NPST:3SG.M road:SG as want:COND:3SG.M Oman

'Und wenn jemand von Aden nach Sawâhil reist, so schlägt er die Richtung nach 'Omān ein' (SAE VI, 35:1-3, al-Hamdānī Jazīra 52:22 = إذاذ (الخارج من عدن إلى بلد الزئ أخذ كأنهيريد عمان

27 The sailor should choose the way "as if he would be heading to Oman" (but in fact not), cf. in the Arabic original. The occasional use of 'égeb 'to wish' with the meaning 'to 
(63) wa- 'émor ho le agében [lạ'gíbin] ó?eho eẓáh hó?o iréৎe and=say:PST:3SG.M 1SG want:COND:1SG brother:PL-POSS.1SG tell:IMP:2SG.M where graze:NPST:3PL.M

'Und er sprach: Ich suche meine Brüder, gib mir Kunde, wo sie weiden!' (SAE VII, 48:1-2, Genesis 37:16 = أنا طالب إخوتي

(64) 'émor iném ta'gében [ta'gíbin] say:PST:3SG.M what want:COND:2SG.M 'Er sprach: Was ist dein Begehr?' (SAE VII, 75:11)

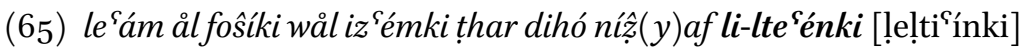
if NEG have_lunch:PST:2DU and=NEG sit:PST:2DU over POSS=1SG carpet:SG kill:COND:1SG-OBJ.2DU

'Wenn ihr bei mir das Mahl nicht eingenommen und auf meinem Teppich gesessen wäret, würde ich euch töten' (SAE VII, 89:22-24, Wagner 1953:152)

2.2.3 The Vienna corpus: poetry

(66) di-bér min hélob yehóre di-Ṣafeḳánoh l(y)ikéren [likírin] REL=be_already:PST:3SG.M of milk:SG search:NPST:3SG.M di_Ṣafekánoh spend_the_night:COND:3sG.M

'Derjenige, welcher kuhwarme Milch sucht, der möge in Brennesseldorf übernachten' (SAE VI, 163:15-16)

(67) fóne lózmien [ḷoṣmíin] lol rínhem lol di-ḥarúfruf ḳarbóbeh earlier die:COND:1SG if:NEG sea:SG if:NEG POSS=sharp_edge:PL Karbóbeh 'Längst wäre ich gestorben, wäre nicht das Meer, und nicht die scharfschneidige Karkómbe' (SAE VI, 184:13-16)

(68) Tho di-Réses le abézin [lậ'bíâiin] if=1SG di_Réses move:COND:1SG

'Wäre ich di-Réses, würde ich mich bewegen' (SAE VI, 235:13, Wagner 1953:152)

be heading to' is closely paralleled by its Jibbali etymological equivalent (Rubin 2014:222) as well as Mehri họm (Rubin 2009).

28 Here the construction seems to be elliptical: 'I would like (to find) my brothers'. 
(69) lahyéren [l'ahyírin] lehó meš nébit lehó toš di-'áțobk 'ásáab tírhi la 'țíbinš [ḷa ${ }^{\top}$ tị́binš] ål kéŝah 'áber half wa-lót i’óte be_good:COND:3SG.M if=1SG of:2SG.F seed:SG if=1SG OBJ.2SG.F REL=pollinate:PST:1S G twig:S G fresh:SG.M pollinate:COND.1SG-OBJ.2SG.F NEG be_dry:PST:SG.M reach:PST:3SG.M female_inflorescence:SG and=then pass:NPST:3SG.M

'Schön wär'es, wenn ich dich befruchten könnte, wenn ich dir ein Reis aufpfropfen würde, ein feuchtes würd'ich pfropfen, nicht ein trockenes. Ist einmal die Stelle passiert, dann gelingt's' (SAE VI, 238:16-19, Wagner 1953:152)

(70) Ibar hélhi wu-lbár dídehi wu-lonḳéylens [ḷonkílins] lbar helóti

if=child maternal_uncle:SG-POSs.1SG and=if=child paternal_uncle:SG-POsS.1SG and=prefer:COND:1SG-OBJ.3SG.F if=child aunt:SG-POSS.1SG

'Der Tochter meines Oheims beiderseits und meiner Tante ziehe ich sie vor' (SAE VI, 242:8)

(71) ldi enátaḳ tió mílak w-eșá aḳ tió lag 'ében [ḷa gíbin]

if=REL shout:NPST:1SG as be_filled:PST:1SG and=scream:NPST:1SG as want:COND:1SG

'Ich möchte brüllen aus voller Brust und möchte schreien nach Herzenslust' (SAE VI, 253:1-2)

(72) 'éḳar heního de bédi w-iném l(y)akénen [l'akínin] le-žálak be_big:PST:3SG.M on:1SG=1SG this:SG.M lie:SG and=what be:COND:3SG.M if=tell:PST:1SG

'Diese Lüge fällt mir gar schwer; was geschieht, wenn ich es melde?' (SAE VI, 255:21-22, same ibid. 280:4, Wagner 1953:152)

(73) di-ål șaúwelob 'átam héyre di é lóklis liṣlébonš [liṣlíbonš] 'aígi hay wulidibon [lidíbon] hemši

REL=NEG slaughter:PASS:NPST:3SG.F fat:SG better REL NEG return:JUS:3SG.M-OBJ.3SG.F slaughter:COND:3DU.M-OBJ.3SG.M man:DU brother:DU and=invite:COND:3DU.M

brother_in_law:SG-POSS.3DU.M

'Daß man keine fette (Kuh) schlachtet für den, der es nicht vergelten kann, ist besser. So mögen die beiden Brüder schlachten und dazu ihre Schwäger einladen' (SAE VI, 341:15-16) 
(74) wa-lól 'eméte di-hólik ladírin [ḷcdírin] be-háriréne

and=if:NEG imte_tree:SG REL=go_under:PST:2SG.M stay:COND:2SG.M in=a_bit

'Hättest du nicht unter dem Imtebaum geweilt, würdest du den Kürzeren ziehen' (SAE VI, 342:9-10)

(75) wu-lómriténken [lomriṭinken] 'ébrehó

and=admonish:COND:1SG-OBJ.2PL grandchild:PL-POSS.1SG

'Ich lege euch ans Herz, meine Kinder' (SAE VI, 358:3)

(76) ål men șaík wa-ål men șaíki gémeméno temóle kérhe ken ního temlé?en [teml'îin] ke héḳomk w-ål dómik

NEG of measure:SG and=NEG of measure:DU broken_vessel:sG

be_filled:NPST:3SG.F except from(=)1SG be_filled:COND:3SG.F if

be_awake:PST:1SG and=NEG sleep:PST:1SG

'Nicht von einem Mass und nicht von zwei Mass wird das gebrochene Gefäss gefüllt, wenn es nicht von mir gefüllt wird, wenn ich wache und nicht schlafe' (SAE IV, 166, No. 10) ${ }^{29}$

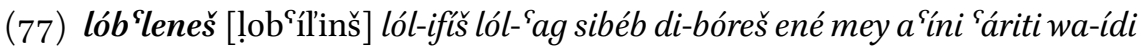
mégdemóti

marry:COND:1SG-OBJ.2SG.F if:NEG father:SG-POSS.2SG.F if:NEG man:SG old:SG.M REL=give_birth:NPST:3SG.M-OBJ.2SG.F that of:3SG.M eye:DU blind:DU.F and=hand:D U cut:DU.F

'Ich heirate dich, wenn auch dein Vater, wenn auch der Alte Mann, der dich gezeugt, an seinen Augen blind ist und seine Hände abgeschnitten sind' (SAE IV, 173 No. 31) 30

2.2.4 CSOL I, II and III

(78) ho !oṭhírin ímšin di-másgid wa-?al-țáherk

1SG go:COND:1SG yesterday towards=mosque:SG and=NEG=go:PST:1SG

'I was about to go to the mosque yesterday, but (in the end) didn't' (CSOL I, $6: 45)$

29 With the following annotation: "Ich vergiesse so viel Thränen, dass das Gefäss, welches zwei Mass nicht füllen würden, durch sie (die Thränen) gefüllt wird".

30 Müller's interpretation of this example is probably incorrect, translate rather 'I would have married you if not for your father ...' (cf. the colloquial Arabic version provided by Müller's informant: نزّوجش ولو ما ابوش ولو ما رجل شيب الذي جابش). 
(79) al-ḥașayk mə`áll'am yhe ligdịhin 'am yhe al-ligdáh NEG=know:PST:1SG teacher:SG 3SG.M come:COND:3SG.M or 3SG.M NEG=come:JU S:3SG.M

'I don't know whether the teacher is coming or not coming' (CSOL I, 6:45)

(80) éz'omk da bə-ḥalf di-ḥa ho lagdáh dỉyho di-ḥalf 'am ho al-logdíhin stay:PST:1SG this:SG.M in=place:SG POSS=here 1SG come:JUS:1SG POSS $=1 \mathrm{SG}$ towards=place:SG or $1 \mathrm{SG} \mathrm{NEG}=$ come:COND:1SG

'I'm staying here, in this land. Will I ever go back to my own land, or won't I go back?' (CSOL I, 6:45)

(81) gédah tan țad ho wa-di'yho `áže wa-kóhob šin wa-lat țáher `améro `áže ؟ ag 'égab siyára 'ámok has lébin šémtal tho la 'bírin 'ay siyára come:PST:3SG.M OBJ:1PL one:M 1SG and=POSS=1SG woman:SG and=spend_the_afternoon:PST:3SG.M with:1PL and=then go:PST:3SG.M say:PST:3SG.F woman:SG man:SG want:PST:3SG.M car:SG say:PST:1SG to:3SG.F if talk:PST:3SG.M OBJ.1SG give:COND:1SG on:3SG.M car:SG 'A certain man visited us, my wife and me, stayed with us during the afternoon and then left. Then my wife said: He wanted our car (for a while). I said to her: If he'd spoken to me, I would have given him the $\operatorname{car}^{\prime}$ (CSOL I, 6:45)

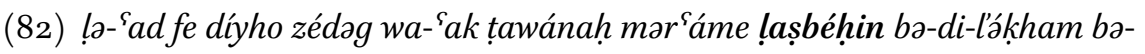
sadhíyo magzéle

if=still_be:PST:3SG.M in:1SG POSS=1SG evil_spirit:SG and=still_be:PST:1SG [uncertain] suspicion:SG

be_in_the_morning:COND:3SG.F in=di_Lékham in $={ }^{\varsigma}$ Edhíyo shame:SG 'If there were an evil spirit in me, or I were a suspicious man, the very next morning there would be shame in di-Leḳham, which is in Edhiyo!' (CSOL I, 6:45, poetry)

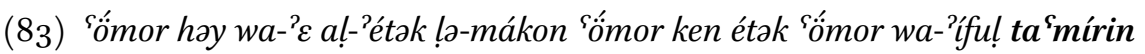

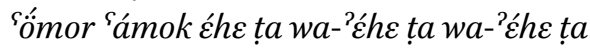
say:PST:3SG.M to:3SG.M and=2SG.M NEG=pasS:PST:2SG.M on=Mákon say:PST:3SG.M but_yes pass:PST:1SG say:PST:3SG.M and=how say:COND:2SG.M say:PST:3SG.M say:PST:1SG behold thus and=behold thus and=behold thus

'He asked: Didn't you pass by the Makon? He said: Yes I passed. He said: And what did you say? He said: I said such-and-such' (CSOL I, 2:21-22) 


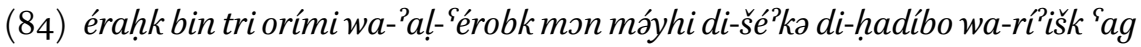
di-késak 'ámok mon man orími di-šé'ka di-hadíbo sómor Éhe daš sámok hay e ta'mírin daš se di-šé'ka

come:PST:1SG between two:F road:DU and=NEG=know:PST:1SG which of:3DU REL=be_near:PST:3SG.F towards=Hadíbo and=ask:PST:1SG man:SG REL=find:PST:1SG say:PST:1SG which of road:DU REL=be_near:PST:3SG.F towards=Hadíbo say:PST:3SG.M behold this:SG.F say:PST:1SG to:3SG.M INTERJ say:COND:2SG.M this:SG.F 3SG.F REL=be_near:PST:3SG.F

'I reached a fork in the road and did not know which way would bring me more quickly to Hadibo. I found a man and asked him. I said: Which of the two roads will bring me more quickly to Hadibo? He said: That one. I said to him: Would you really say this one is quicker?' (CSOL I, 2:22)

(85) gédaḥk di’ál é'hi wa- 'ámok hay 'érobk mon da di-gó?or Sáyki dỉki kậar 'ómor l'a 'ámokfal'an 'ómor ع ta'mírin

come:PST:1SG towards brother:SG-POSS.1SG and=say:PST:1SG to:3SG.M know:PST:2SG.M who this:SG.M REL=destroy:PST:3SG.M on:1DU POSS=1DU house:SG Say:PST:3SG.M no say:PST:1SG so_and_so say:PST:3SG.M INTERJ Say:COND:2SG.M

'I came to my brother and said to him: Do you know who destroyed our house? He said: No, I don't. I said: Such-and-such a man. He said: Do you really say this?' (CSOL I, 2:22)

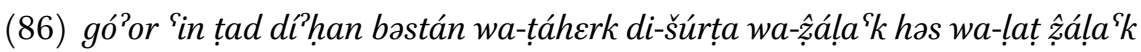
e-'ó'ḥo 'émar wa-'iful ta'mírin e-šúrța destroy:PST:3SG.M on:1PL one:M POSS=1PL palm_grove:SG and=go:PST:1SG towards=police:SG and=tell:PST:1SG to:3SG.F and=then tell:PST:1SG to=brother:PL-POsS.1SG say:PST:3PL.M and=how say:COND:2SG.M to=police:SG

'Someone destroyed our palm grove. I went to the police and told them. Then I told my brothers about it. They said: What exactly did you tell the police?' (CSOL I, 2:22) 


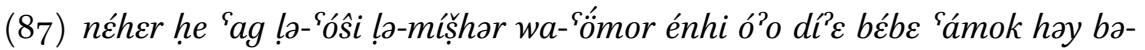

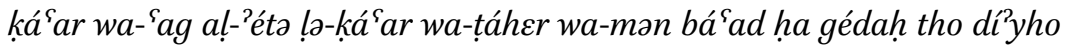
bébe wa-'ámok hay rî́iš mak tad 'ag ؟ömor énhi íful ta'mírin énhi pass_by:PST:3SG.M on:1SG man:SG on=dawn:SG on=pen:SG and=say:PST:3SG.M to:1SG where POSS=2SG.M father:SG say:PST:1SG to:3SG.M in=house:SG and=man:SG NEG=pass:PST:3SG.M on=house:SG and=go:PST:3SG.M and=of after here come:PST:3SG.M OBJ:1SG POSS=1SG father:SG and=say:PST:1SG to:3SG.M ask:PST:3SG.M of:2SG.M one:M man:SG say:PST:3SG.M to:1SG how say:COND:2SG.M to:1SG 'At dawn a man came to see me in the pen and said to me: Where is your father? I said to him: At home. The man did not want to pass by the house and left. Afterwards my father came to me. I told him: There was someone asking about you. He said: What exactly did you tell him about me?' (CSOL I, 2:22)

(88) ؟ómor ŝíbeb $\varepsilon$ ta $a^{\varsigma}$ mírin say:PST:3SG.M old_man:SG INTERJ Say:COND:2SG.M 'The old man said: What are you saying?' (CSOL I, 28:33)

(89) á'yhofk tay óoz di-'ibóho wa-se !̣a ágən wa-hérək lahréwa-'al-ksek lose:PST:1SG one:F goat:SG REL=be_pregnant:PST:3SG.F and=3SG.F give_birth:COND:3SG.F and=seek:PST:1SG seek:JUS:1SG and $=$ NEG $=$ find:PST:1S G 'I lost one of my goats which was pregnant and might have given birth. I tried to look for it, but could not find it' (CSOL I, 14:7)

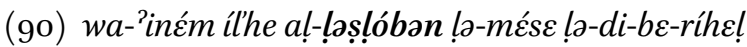
and=what this:PL NEG=slaughter:PASs:COND:3 PL.M on=rain:SG on $=\mathrm{REL}=$ without $=$ (uncertain) 'But why (these animals) should not be slaughtered (to ask) for rain from the Almighty?' (CSOL II, 5:7, poetry, forthcoming)

(91) mən ḥa hárḩar á'yag təro məŝtinézo latakífin of here Hárḥər give_birth:NPST:3SG.F two:M slanted:SG.F improve:COND:3SG.F

'Thanks to this Hárḩør will bear a twin, and the one with a slanted teat may improve' (CSOL II, 5:13-14, poetry, forthcoming) 
(92) émme ránham latréfan 'es ketáh fadénhin latckíizin

either sea:SG wrap:COND:1SG on:3SG.F or_else mountain:PL make_clench:COND:1SG

II would wrap the sea around them, or else make the mountains clamp down on them' (CSOL II, 5:17-18, poetry, forthcoming)

(93) Ŝ́nik 'ag di-hómil' la-humára kas wa-?óbhon kor ya ámar nhofš staróuno 'ámok yo géšalk dî́ humára 'ömor ys al-di'yho 'ámok ken da be náțin al-

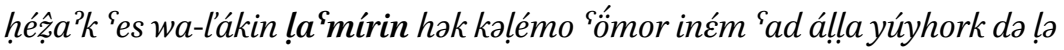
néfa $a^{\varsigma}$ i-ḥa

see:PST:1SG man:SG REL=load:PST:3SG.M on=she_ass:SG clay:SG and=stone:PL so_that make:NPST:3SG.M REFL:3SG.M little_hut:SG say:PST:1SG INTERJ break:PST:2SG.M POSS=2SG.M she_ass:SG say:PST:3SG.M INTERJ NEG=POSS=1SG Say:PST:1SG from this:SG.M (uncertain) actually NEG=Spare:PST:2SG.M on:3SG.F and=but say:COND:1SG to:2SG.M little_word:SG say:PST:3SG.M what still_do:PST:3SG.M God follow:NPST:3SG.M-OBJ.2SG.M this:SG.M on=affair:SG POSS=here 'I saw a man who loaded on his she-ass clay and stones to build a little hut for himself. I said to him: Hey, you are going to break your donkey! He said: It is not mine. I said: That's why you don't spare it. But may I say you one little word? He said: What is it? I said: God will prosecute you for this affair of yours' (CSOL III, 13:7, forthcoming)

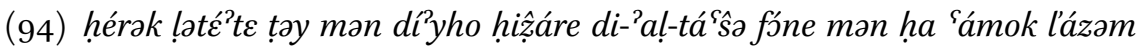
šadfó'o ba-bsheléno karére sínik ba-kendhíyo di-ḳon á'rab wa-sou'ído žerk 'af bok wa-ksek tos bikémo sérhon wa- ${ }^{2} a !-$ šés $^{\prime}$ ad has la ${ }^{\text {s }}$ mírin bar gerb seek:PST:1SG call_back:JUS:1SG one:F of POSS=1SG house_goat:SG REL=NEG=get_up:NPST:3SG.F earlier of here say:PST:1SG surely stumble:PST:3SG.F in=little_thing:SG tomorrow see:PST:1SG in=bottom:SG POSS=peak:SG raven:SG and=vulture:SG rush:PST:1SG until there and=find:PST:1SG OBJ:3SG.F be_lame:PST:3SG.F foot:PL and=NEG=be_possible_to_walk:PST:3SG.M to:3SG.F say:COND:1SG that mange:SG

'I tried (in vain) to call back one of my house-goats who had never moved from here before. And I said to myself: It must have stumbled upon something. On the next day I saw ravens and vultures at the foot of a steep mountain. I rushed there and found my goat lame on its feet, it was unable to walk. I would say, it had mange' (CSOL III, 15:5, forthcoming) 


\subsection{Morphological and functional analysis}

The full paradigm of the Soqotri $n$-conditional in the basic stem exemplified by rékob 'to ride' as elicited from our informants looks as follows.

\begin{tabular}{llll}
\hline & sg. & du. & pl. \\
\hline $\mathbf{1}$ & lerkíbin & lerkíbon & nerkíbin \\
$\mathbf{2} \mathbf{m .}$ & terkíbin & terkíbon & terkében \\
$\mathbf{f .}$ & terkíbin & & terkébnen \\
$\mathbf{3} \mathbf{m .}$ & l'irkíbin & l'irkíbon & l'irkében \\
$\mathbf{f .}$ & terkibin & terkibon & terkébnen \\
\hline
\end{tabular}

The distribution of the attested examples over the three text types which compose our corpus reveals the following picture:

original prose: (58)-(61) in the Vienna corpus (4 examples), (78)-(81),

(83)-(89), (93)-(94) in Csol (13 examples)

translated prose: $(62)-(65)$ in the Vienna corpus ( 4 examples)

poetry: (66)-(77) in the Vienna corpus (14 examples) ${ }^{31}$, (82), (90)-(92)

(twice) in csol ( 5 examples)

While certainly prominent in the poetic texts, the $n$-conditional is by no means limited to them. Even in the Vienna corpus, the non-poetic examples (8) are only slightly less numerous than the poetic ones $(\mathbf{1 3}),{ }^{32}$ whereas most of the CSOL examples stem from lexical illustrations imitating the modern everyday speech of the islanders (including dialogues). All in all, one can confidently say that the $n$-conditional, while not the most actively used element of the Soqotri verbal system, is a living and productive grammatical feature ${ }^{33}$ rather than a frozen poetic archaism as one might deduce from Wagner's pioneering remarks on the subject.

\footnotetext{
31 Twice in (69) and (73).

32 Here again, the dichotomy between translated and original prose can hardly be of any relevance: in none of the pertinent four cases are there any reasons to suspect that the use of the $n$-form in the Soqotri text was induced by a structurally and/or functionally comparable form in the original.

33 Certainly no less living than its matches in the continental MSA, described as "(extremely) rare" in Rubin's recent comprehensive grammars of Omani Mehri and Jibbali (2010:132, 2014:152).
} 
One can tentatively posit the following functions of the conditional in Soqotri.

A. As a verbal form not involved in a conditional sentence.

A.1. Counterfactuality, understood here as an indication that the situation involved is "contrary to the fact", that it, believed by the speaker not to take place, not to belong to the real world, etc. In main clauses, it is usually combined with the semantics of desire of the speaker, as in If only he could understand ${ }^{34}$

A.2. Possibility, understood here as an indication that the situation is possible, but not necessarily taking place in the reality, as in He may have seen us.

A.3. Optativity, understood here as expression of hope or demand of the speaker, as in Let him come! (note that, in our understanding, optativity is not identical to counterfactuality as described above). Optativity is one of the primary functions of the Soqotri jussive, and it remains to be established whether there is any semantic or functional difference between jussive and $n$ conditional when used in the "optative" meaning. ${ }^{35}$

A.4. Politeness, that is, expression of polite attitude of the speaker towards the listener. The use of epistemic or optative grammemes in this function is a wellknown phenomenon, as in I would like to thankyou. ${ }^{36}$

B. In conditional sentences, one should distinguish between two functions of the conditional, that is, to mark unreal and real conditional sentences. The former use can be plausibly considered a representation of counterfactuality (Iatridou 2000). As for the use of the conditional in real conditional sentences, one can tentatively interpret these forms as possibility markers. ${ }^{37}$

34 See Iatridou 2000, where counterfactual wishes are claimed to be the only type of counterfactuality outside the context of a conditional sentence.

35 That the plain jussive and the conditional can indeed be interchangeable is to be deduced from the similarly structured examples (79) and (80): while in the former case the positive alternative is expressed by the conditional and the negative by the jussive, the latter shows the reverse morphological arrangement.

36 In Dendale 2001:13-14 the term "attenuation" is used alongside "politeness" (see also Vincent 2013:129-130).

37 On the use of possibility markers in the protases and, more frequently, apodoses of conditional sentences v. Bybee et al. 1994:208-210. 
Below, the attested examples of the Soqotri conditional known to us are arranged according to these functions.

A.1. Counterfactuality: (62), (78), (92) (twice).

A.2. Possibility: (80), (89), (90), (91) (in main clauses); (79) (in a subordinate clause). Most examples refer to the future, which is the default use of possibility morphemes (Bybee et al. 1994:207); only example (89) refers to the past. ${ }^{38}$ Note that, among the main clause attestations, two $((80)$ and $(90))$ involve question sentences, whereas the only example in a subordinate clause is in an indirect question.

A.3. Optativity (in main clauses only): (66), (73) (twice), (75).

A.4. Politeness ("attenuation"): (63), (64), (71) (forms of 'égeb 'to want'); (83)(88), (93), (94) (forms of 'émor 'to say'). The usage of the $n$-conditional interpreted here as "polite" is restricted to the verbs with the meaning "to want" and "to say" in the 1st and 2nd person, which fits exactly the observations of Dendale 2001:9: in French, the use of the conditional with the function of "attenuation" (politeness) is mostly attested with verbs of desire, obligation and speech. ${ }^{39}$ Note, however, that the conditional forms of 'émor 'to say' do not seem to be perceived as polite by the speakers themselves, ${ }^{40}$ so one is forced to interpret them as fossilized forms whose original meaning has been bleached out. ${ }^{41}$ Note that 6 of the 8 attested conditional forms of 'émor $((83)-(88))$ are found in questions.

38 Within an alternative interpretation, the $n$-conditional in this example can be taken to render future in the past ("a goat that was going to give birth").

39 "Conditionnel d' atténuation du vouloir, du devoir, du dire". It is likely not by chance that the cognate Jibbali verb 'ágeb 'to want' is the only one whose conditional seems to be regularly used outside the apodoses of unreal conditional clauses (Rubin 2014:224, mostly in $\left.1 \mathrm{pl} . n a^{\varsigma} g \bar{u} n\right)$, whereas the $2 \mathrm{sg}$. m. conditional of 'ór 'to say' has been lexicalized as the comparative preposition ta'míran 'like' (ibid. 263).

40 In most cases, they are rather inclined to attach to such examples the meaning of doubt, uncertainty ("Did/do you really say (this)?").

41 That the $2 \mathrm{~m}$. sg. form of the $n$-conditional of the verb with the meaning "to say" indeed tends to become a fossilized lexical element is made plain by the fate of the cognate Jibbali form mentioned in fn. 39 ("like" < "as you would say"). 
B.1. Counterfactuality (in apodoses of unreal conditional clauses): (59), (65), $(67)-(70),{ }^{42}(72),(74),(77),(81),(82)$.

\section{B.2. Possibility}

- in protases of real conditional sentences: $\left(5^{8}\right),(60),(61) \cdot{ }^{43}$

- in the apodosis of a real conditional sentence: $(76)$.

The survey of the relevant passages allows one to observe that the Soqotri $n$ conditional is unmarked for tense: the same form can refer to the present (as in $(63),(64),(84),(85),(88),(94))$, past $((67),(78),(83),(86),(87),(89))$ or future time ((58), (6o), (61), (79), (8o), (91)).

One clear-cut conclusion of our analysis is that apodoses of unreal conditional sentences - the only syntactic slot codified for the $n$-form in both Soqotri and continental MSA in the standard descriptions since Wagner 1953 onwards ${ }^{44}$ _ constitute a relative minority of the attested cases.

One may hope that here, as in many other cases, the extremely rich and archaic linguistic landscape of Soqotra will be capable of providing scholars

42 While the structure of the example (70) seems to be identical with that of a conditional sentence, it is likely to be interpreted as a concessive clause with an unreal condition: "Even if [I were offered] the daughter of my uncle and the daughter of my aunt, I would have married you" (v. Heine-Kuteva 2002:93 on the grammatical shift "conditional" > "concessive"). It is unlikely that Müller's $l$ in this case stands for the preposition le- 'on, over' (rather than the homonymous marker of the unreal conditional clause): as one can deduce from the examples collected in LS 274 (as well as in the unpublished texts of CSOL II), nókal 'to prefer' is always construed with 'an rather than $l e-$.

43 In all these examples, we are dealing with the verb "to die" used in the 1st person; one can suspect some kind of a linguistic taboo (viz. avoidance of direct mentioning of one's death as an inevitable event). If this surmise is correct, the function of the $n$-conditional in this context is close to what is termed "attenuation" by some authors (cf. A.4.).

44 Let us note that the most recent studies on this topic seem to reveal a more complex picture. Thus, as kindly pointed out to us by Aaron Rubin, at least one example of a freestanding conditional is attested in Johnstone's Jibbali texts (Rubin 2014:152), apparently with no special semantic load if compared to the normal jussive. One more example could be spotted in the Jibbali Vienna corpus (where the very presence of the $n$-conditional has gone unrecognized so far): be-na dénu la gín (la gében) le-gád šek 'Und jetzt möchte ich mit dir gehen' (SAE VII 10516). Also Janet Watson (2012:92) mentions several examples of optative conditionals outside the unreal conditional sentences in Omani Mehri, such as afrihhan bih 'I would be glad of it' (as observed by Watson, the conditional forms used in this way curiously lack the $l$-prefix). 
with new insights on the diachronic background of the MSA $n$-conditional and its possible cognates outside this group. ${ }^{45}$

\section{Appendix. On the unreal conditional sentences in Soqotri}

Since the unreal conditional sentence is the most prominent syntactic context where the $n$-conditional can appear in Soqotri, it seems reasonable to make a preliminary survey of the structure of unreal conditional sentences as attested in the published texts. Since in each of the three volumes of CSOL this construction is rather uncommon, we shall start our investigation with the Vienna corpus where a relatively broad inventory of pertinent syntactic slots can be found (most prominently, in SAE VI).

In eleven examples (treated in the main part of this article) the protasis, introduced with one of the particles of unreal condition, ${ }^{46}$ displays the perfect (or else the clause is verbless), whereas in the apodosis the $n$-conditional is found: (59), (65), (67), (68), (69), (70), (72), (74), (77), (81), (82).

More seldom both the apodosis and the protasis display the perfect:

(95) le ám 'éygib állāh l(y)óșim tan ål-zêe e min dihán mínne ídi mékbib wanidákoh wål ŝénne tan dešfáhere wål šmaḥ-tan dé be-'émed tió deš if want:PST:3SG.M God make_die:JUs:3SG.M овJ:1PL NEG=take:PST:3SG.M of POSS=1PL of hand:DU burnt_offering:SG and=offering:SG and=NEG show:PST:3SG.M OBJ:PPL this:SG.F all and=NEG make_hear:PST:3SG.M OBJ.1PL this:SG.M in=time:SG as this:SG.F

'Wenn Gott uns töten wollte, so hätte er aus unserer Hand nicht Ganzund Speiseopfer angenommen, hätte uns nicht alles das sehen lassen und zur Zeit uns nicht solches hören lassen' (SAE VI, 17:9-13 = Judges 13:23)

45 For a recent survey on this hotly debated issue v. Kogan 2015:136-143 and 473-474.

46 The main lexical marker of the unreal condition in Soqotri is the particle le (< PS *law), which can be expanded to le- ${ }^{\varsigma} a m$, lébin or lémin. As far as the latter form is concerned, there is an intriguing possibility of comparing the element -min to Akkadian -man (Old Assyrian -min!) in šumma-man/šumma-min with exactly the same function (KrebernikStreck 2001:52-53). Also noteworthy is the Tigre particle man, admittedly introducing real rather than unreal conditional clauses (Littmann-Höfner 1962:126). Negative unreal conditions are introduced with the particle $l a l$, presumably $<{ }^{*} l e-{ }^{2} a !$. 
(96) le ám ål rimósken dihó le-2arḥ ål kesékin dihó thạtịoh

if NEG plough:PST:2PL POSS=1SG on=heifer:SG NEG find:PST:2PL $\mathrm{POSS}=1 \mathrm{~S} \mathrm{G}$ riddle:S $\mathrm{G}$

'Hättet ihr nicht gepflügt mit meiner Kalbin, so würdet ihr mein Rätsel nicht gefunden haben' (SAE VI, 19:27-28 = Judges 14:18)

(97) Le ám íål dómiš ål heéborš ițá

if 2SG.F NEG sleep:PST:2SG.F NEG experience:PST:2SG.F thus

'Hättest du nicht geschlafen, so würdest du das nicht erlitten haben' (SAE VI, 221:9)

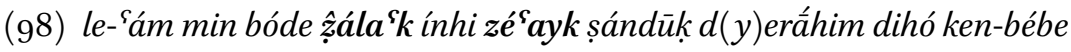
if of beginning:SG tell:PST:2SG.M to:1SG take:PST:1SG chest:SG $($ POSS $)=$ money $:$ PL POSS $=1$ SG from $=$ father:SG 'Wenn du mir es vom Anfang an gesagt hättest, würde ich einen Koffer mit Geld von meinem Vater genommen' (SAE VII, 77:12-14)

No perceptible difference between the two types of usage could be detected.

Among the few relevant examples attested in CSOL I-III, two cases dealt with above $((81)$ and $(82))$ display the $n$-conditional in the apodosis and the perfect (or a verbless clause) in the protasis.

Surprisingly, not a single example with the perfect in the apodosis has been detected. Instead, there are several reliable cases where this function is performed by the imperfect:

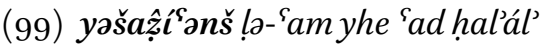
slaughter:NPST:3SG.M-OBJ.3SG.M if 3SG.M still_be:PST:3SG.M licit 'He would have slaughtered it, had it been suitable for food' (CSOL I 8:55)

(100) lémin rik toy ya `áḳob ŝhaf wa-yoṣáḳob if drink:PST:2SG.M OBJ:3SG.M turn_into:NPST:3SG.M milk:SG and=coagulate:NPST:3SG.M 'If you drank it, it would have turned to real milk and then yielded fresh butter' (CSOL II 7:41, forthcoming)

(101) lémin fátḥaš əšórš fagrémo di- ${ }^{2} i f s ̌ s$ if fall:PST:3SG.M make_follow:NPST:1SG-OBJ.2SG.F skull:SG POSS=father:SG-POSS.2SG.F

'If it fell, I would have made you follow the skull of your father' (CSO L II 30:23, forthcoming) 


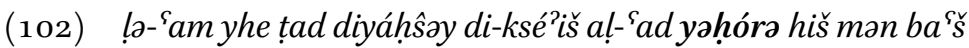
if 3 SG.M one:M other:SG.M REL=find:PST:3SG.M-OBJ.3SG.M NEG=still_be:PST:3SG.M seek:NPST:3SG.M to:3SG.M of owner:SG-POSS.3SG.M

'If it were somebody else, not he, who would have found it, he would not have looked for its owner' (CSOL II $30: 18$, forthcoming) ${ }^{47}$

(103) wa-heb !̣-réżš énhi míe wa-tilliš bo-moḷaháyhon wa ${ }^{48}{ }^{\varsigma} a k$ aḥáṣak bosémmo wa-'akténaḥ bas 'an ŝál'he and=indeed if=bribe:PST:2SG.F to:1S G hundred:SG and=add:PST:2SG.F in=domestic_goat:PL and=still_be:PST:ISG return:NPST:1SG in=Sémmo and=come_back:NPST:1SG in:3SG.F from little_thing 'Even if you bribed me with a hundred and added more domestic goats, I would have come back to Semmo and returned to her for nothing' (CSOL II 24:12, forthcoming)

\section{(104) l'aw al-'éntab yadáras}

if NEG=part_the_legs:PST:3SG.M reach_the_mark:NPST:3SG.M 'If he did not part the legs, he would have reached the mark' (CSOL III 15:3, forthcoming $)^{49}$

These six examples can scarcely be discarded as accidental and must represent a certain trend towards the structural renewal of the unreal conditional sentence: instead of the archaic $n$-conditional and the (perhaps more innovative) perfect, the syntactic slot of the apodosis is now more commonly marked with the imperfect. No fully transparent forerunners of this construction could be detected in the Vienna corpus, but cf. perhaps the following lone example from SAE VI, 159:10-11:

\footnotetext{
47 In this and the following examples, the imperfect in the apodosis is preceded by the predicative element ${ }^{S} a d$ whose combination with the main verb means 'to do yet, to do further' (Naumkin et al. 2014:503).

48 This is, presumably, the waw of apodosis, whose presence in Soqotri remains to be substantiated by further research.

49 In this example the protasis is exceptionally introduced with the particle l'aw borrowed from Arabic.
} 
(105) le lémho țófef ål mósìig min fiḳha ål še Séleḳen

if=1SG thin:SG.M NEG massive:SG.M of garment:SG NEG despise:PASS:NPST:1SG

' $\mathrm{O}$, wäre ich doch dünn und nicht so massig, daß sie mich Kleider wegen nicht verschmähen'.50

\section{References}

Bittner 1917-1918—M. Bittner. Einige Besonderheiten aus die Sprache der Insel Soqoțra. WZKM 30:347-358.

Bittner 1918a-M. Bittner. Charakteristik der Sprache der Insel Soqotra. Anzeiger der philosophisch-historischen Klasse der kais. Akademie der Wissenschaften in Wien 55: 48-83.

Bittner 1918b-M. Bittner. Vorstudien zur Grammatik und zum Wörterbuch der SoqotriSprache. III. Eine Soqotri-Version der ersten sechs Kapitel aus dem Marcus-Evangelium. Wien.

Bybee-Perkins-Pagliuca 1994-J. Bybee, R. Perkins, W. Pagliuca. Evolution of Grammar. Tense, Aspect and Modality in the Languages of the World. Chicago-London. CSOL I = Naumkin et al. 2014.

Dendale 2001—P. Dendale. Les problèmes linguistiques du conditionnel français. Le conditionnel en français. Metz. Pp. 7-18.

Heine-Kuteva 2002-B. Heine, T. Kuteva. World Lexicon of Grammaticalization. Cambridge.

Iatridou 2000-S. Iatridou. The Grammatical Ingredients of Counterfactuality. Linguistic Inquiry 31:231-270.

JL-T.M. Johnstone. Jibbāli Lexicon. Oxford, 1981.

Johnstone 1968-T.M. Johnstone. The Non-Occurrence of a $t$-Prefix in Certain Socotri Verbal Forms. BSOAS 31:93-121.

Johnstone 1975-T.M. Johnstone. The Modern South Arabian Languages. Afroasiatic Linguistics 1:93-121.

Johnstone 1980-T.M. Johnstone. The Non-Occurrence of a t-Prefix in Certain Jibbāli Verbal Forms. BSOAS 43:466-470.

Kogan 2015-L. Kogan. Genealogical Classification of Semitic. The Lexical Isoglosses. Berlin.

50 A more literal translation seems to be "If I were thin and not so massive, I would not be despised because of the garments". The verbal form in the apodosis is to be parsed as the 1 sg. Imperfect of the passive voice from the causative-reflexive intensive verb še salik 'to despise'. 
Krebernik-Streck 2001-M. Krebernik, M. Streck. šumman lā ḳabiāt ana balāțim ... Wärst du nicht zum Leben berufen ... Der Irrealis im Altbabylonischen. Sachverhalt und Zeitbezug. Semitistische und alttestamentliche Studien Adolf Denz zum 65. Geburtstag. Wiesbaden. Pp. 51-78.

Lane-E.W. Lane. Arabic-English Lexicon. London, 1867.

Littmann-Höfner 1962-E. Littmann, M. Höfner. Wörterbuch der Tigrē-Sprache. Wiesbaden.

Lonnet 1993-A. Lonnet. Quelques résultats en linguistique sudarabique moderne. QSA 11:37-82.

Naumkin et al. 2013 - V. Naumkin, M. Bulakh, L. Kogan. Two Erotic Stories from Soqotra Revisited. Babel und Bibel 7:527-563.

Naumkin et al. 2014-V. Naumkin, L. Kogan, 'I. al-Da'rhi, A. al-Da'rhi, D. Cherkashin, M. Bulakh, E. Vizirova. Corpus of Soqotri Oral Literature. Volume One. Leiden.

Naumkin et al. 2015 - V. Naumkin, L. Kogan, A. al-Daarhi, I. al-Daarhi, D. Cherkashin. Soqotri Texts in the Phonogrammarchiv of the Austrian Academy of Sciences. An Annotated Edition. Oxford.

Naumkin et al. 2016-V. Naumkin, M. Bulakh, D. Cherkashin, L. Kogan, A. Issa, I. Gumaan, M. Mohammed. Studies in the Verbal Morphology of Soqotri. II. Weak and Geminated Roots in the Basic Stem. ZAL 63:19-61.

Rubin 2009-A. Rubin. hōm Sweet ḥōm. The Unusual Mehri Verb 'To Want'. zAL 51:7684.

Rubin 2010-A. Rubin. The Mehri Language of Oman. Leiden-Boston.

Rubin 2014-A. Rubin. The Jibbali (Shahri) Language of Oman. Leiden-Boston.

SAE IV-D.H. Müller. Die Mehri- und Soqotri-Sprache. I. Texte. Wien, 1902.

SAE VI-D.H. Müller. Die Mehri- und Soqoțri-Sprache. II. Soqoțri-Texte. Wien, 1905.

SAE VII-D.H. Müller. Die Mehri- und Soqotri-Sprache. III. Šhauri-Texte. Wien, 1907.

Simeone-Senelle 1997a-M.-C. Simeone-Senelle. The Modern South Arabian Languages. The Semitic Languages. London. Pp. 378-423.

Simeone-Senelle 1997b-M.-C. Simeone-Senelle. Suḳțtra. 3. Language. EI 9:809-811.

Simeone-Senelle 2011-M.-C. Simeone-Senelle. Modern South Arabian. The Semitic Languages. Berlin-Boston. Pp. 1073-1113.

Testen 1992-D. Testen. The Loss of the Person-Marker $t$ - in Jibbali and Socotri. BsOAS 55:445-450.

Vincent 2013-N. Vincent. Compositionality and Change in Conditionals and Counterfactuals in Romance. The Boundaries of Pure Morphology: Diachronic and Synchronic Perspectives. Oxford. Pp. 116-136.

Wagner 1953-E. Wagner. Syntax der Mehri-Sprache unter Berücksichtigung auch der anderen Neusüdarabischen Sprachen. Berlin.

Wagner 1993-E. Wagner. Gedanken zum Verb des Mehri aufgrund der neuen Materialien von Johnstone. ZAL 25:316-339.

Watson 2012-J. Watson. The Structure of Mehri. Wiesbaden. 